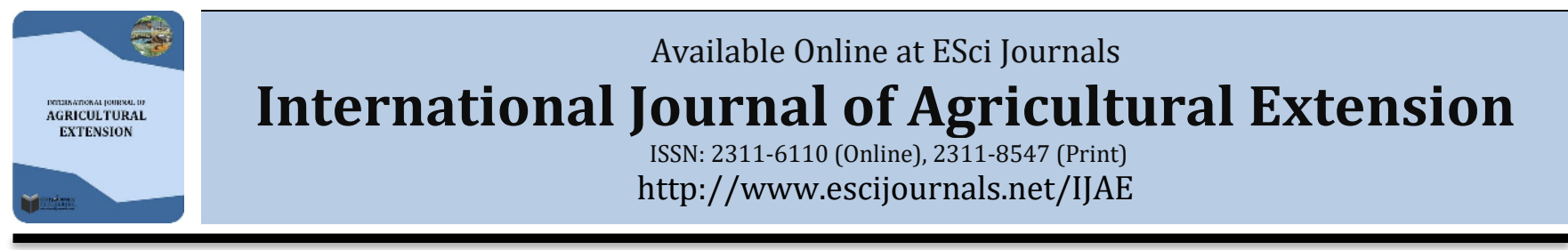

\title{
EFFECTS OF FARMERS' SOCIOECONOMIC CHARACTERISTICS ON ACCESS TO AGRICULTURAL INFORMATION IN NGAKA MODIRI MOLEMA DISTRICT OF THE NORTH WEST PROVINCE
}

\author{
a,bSinah M. Modirwa \\ a Department of Agricultural Economics and Extension, Faculty of Natural and Agricultural Sciences, North-West \\ University, P Bag x2046, Mmabatho 2735, Mafikeng, South Africa. \\ b Food Security and Safety Niche Area, School of Agricultural Sciences, North west University, Mmabatho, 2735 - \\ South Africa.
}

\begin{abstract}
A B S T R A C T
Information plays an important role in enhancing agricultural development. Agricultural extension exchange information with farmers to improve their production, however, farmers use other sources to access the information they need to improve their production. However, their access to agricultural information may be hindered by some socio-economic characteristics. Therefore, the current study identified the effects of farmers' socioeconomic characteristics, their sources of agricultural information and the constraints they face in accessing agricultural information. A proportionate sample of 120 respondents was selected randomly from the participants. The data was collected through a pre-tested questionnaire and Statistical Package for Social Sciences (SPSS) was used to perform statistical analysis. Descriptive statistics such as frequency and percentages were used. On the basis of to what extend different information sources were used by farmers the rank order was used. Further, bivariate analysis was used to test the level of association among selected variables. The results show that the majority of the respondents were over the age of fifty and were males. Most of the respondents went up to high school level of education. More respondents had a land size of up to five hectares. Further, the results showed that there existed a significant relationship between respondents' age, education and their sources of information. The results further revealed that fellow farmers and extension staff were the major sources of information. However, distance from the extension staff and lack of awareness of new technology were identified as the constraints that the respondents face in accessing agricultural information. The results of the study therefore reveal that there is a need for farmers to access relevant and timeous agricultural information to improve their production.
\end{abstract}

Keywords: Income, community, development, poverty.

\section{INTRODUCTION}

Empowering farmers' starts with information because it plays a pivotal role in increasing agricultural production and improving marketing and distribution strategies (Rehman et al., 2013). According to Mittal \& Mehar (2015) adoption of information, and any actions based on it, relies heavily on where people source it from. In addition, having a more targeted approach to disseminating agriculture-related information can ensure that information reaches as many farmers as possible and takes into account the diversity of sources

* Corresponding Author:

Email: Sinah.Modirwa@nwu.ac.za

(C) 2019 ESci Journals Publishing. All rights reserved. that farmers rely on. Extension service is mandated to disseminate agricultural information to farmers to assist them to improve their production and in return, achieve food security and income generation. The North West Province is an important food basket in South Africa. Maize and sunflower are the most important crops, and the province is the major producer of white maize Young (2016). Agriculture is the only sector apart from mining in which the Province is acknowledged to have a comparative advantage over the other provinces. The agricultural sector produces $13 \%$ of provincial GDP and provides jobs for $18 \%$ of the labour force in the province. The Province produced $2 \%$ of all the commercial maize grown in South Africa, of which $78 \%$ 
was white maize and $22 \%$ yellow maize. In spite of such great importance, agriculture is developing at a very slow speed in the province. Abbas et al (2008) argue that the lack of information and lack of technical knowledge at farm level are the major factors contributing to low yield and slow production.

Information has become the chief determinant of the progress of nations, communities and individual (Sanap, 2015). Bawa (2014) emphasised that agricultural information is considered as a productive resource limiting and influencing the efficiency of production as it shapes farmers decision making and that farmers should have the latest information regarding among others new farming techniques, water management, marketing of products etc. The extension agents carry out the responsibilities of educating and disseminating useful and timely agricultural information to farmers, further Bawa (2014) argues that farmers' source of information shape farmers' decision making. In addition, Agricultural information is a major tool for the development of smallscale farmers and contribute to the livelihood of people in both rural and urban area Ronald (Silayo \& Abdalah, 2015). However, Obidike (2011) found that rural farmers face widening information gaps and therefore it is difficult for them to compete in the global market or even adopt improved technology (Aina in Obodike 2011:1) opined that farmers would benefit from global information if information centres are dispersed in rural areas. However, the efficiency of information disseminated depends on effective information sources. In agriculture, the role of information cannot be overemphasized in enhancing agricultural development. Today, in the age of information and technology, the dissemination of information becomes much easier yet more complex, this is because of information messages need to be disseminated to farmers in the manners and methods, which are appropriate, and best suit the needs of farmers. There are a variety of sources of information dissemination including among others result in demonstration, general meetings, group discussion, lectures, television, radio, cinema, leaflets, bulletins, letters, circulars, etc.

In the study area, to enhance the agricultural productivity the Department of Rural Environment and Agricultural Development is responsible for disseminating information to farmers. However, In spite of all these efforts by the Department, farmers have low accessibility to agricultural information. Ortmann \& King
(2008), confirms that in rural areas of South Africa Small scale farmers have limited access to factors of production including information. Khapayi \& Celliers (2016) identified various reasons for low accessibility to agricultural information, such as: poor roads, poor transportation from farms to markets, lack of marketing skills and information, insufficient land availability to expand production, lack of agricultural implements to better production, poor production and management skills and low levels of education. The Department of Rural Environment and Agricultural Development through extension and advisory service encourage collaboration and grouping of farmers with similar problems to enable them to benefit from working together and share information. Agricultural information will help farmers make informed decision regarding agricultural practices. However, Rehman (2013: 325) argues that socio-economic variables may influence the accessibility to agricultural information of the farmers. Therefore, the main objective of the study was to identify the socio-economic characteristics affecting information access among farmers in the North West Province.

\section{MATERIALS AND METHODS}

The study area: The study was conducted in Ngaka Modiri Molema District which is a category C municipality and one of the four district municipalities in the North West Province of South Africa. The district is situated centrally within the province and shares an international border with Botswana country. It comprises of five local municipalities: Mahikeng, Ratlou, Ramotshere Moiloa, Ditsobotla and Tswaing. The villages selected as the study sites in the province were: Lokaleng, Ramatlabama, Magogwe and Modimola. These villages among others are characterised by service delivery backlogs and the members depend on services located far from their place of living and have to spend money and time to access basic needs, Ditau GEOinformatics solutions (2016).

Sample selection: A simple random sampling technique was used for the sample selection, according to Alvi (2016), in this type of sampling each and every element of the population has an equal chance of being selected in the sample. The sampling frame included small-scale farmers registered on the North West Department of Agriculture data base. To determine the sample size, a table designed by Krejcie \& Morgan (1998) as quoted by Mburu (2013) was used. The table gave the required 
sample size for various population sizes and Ngaka Modiri Molema with a population of 1449 small-scale farmers fell under 302 and of the 302 samples, only 120 small-scale farmers volunteered to participate.

Research design: A quantitative research design was used for this research study. This approach was chosen for because it provides reliable data on the numbers of participants who reveal a range of different attitude and behaviours. The approach also provides in depth information and provides the researcher with the opportunity to sample large numbers of population.

Data collection: A structured questionnaire was used to collect quantitative data from the respondents. Before the administration of the questionnaire, the respondents were informed about the objectives of the survey and the enumerator trained on the objective. The questionnaire which consisted of three (3) sections was first pre-tested for reliability and validity of the survey questions before the actual data collection. The first section identified the socio-economic characteristics of respondents such as age, gender, educational level, farming experience, farm size. The second section identified different information sources used by farmers in accessing agricultural information while the third section identified the constraints encountered by farmers in accessing agricultural information.
Data analysis: The data collected was coded by assigning a numerical value to each variable in order to facilitate easier workability on the SPSS program version 21. The Microsoft Office Excel 2010 software package was used to capture the coded data. Descriptive statistics such as frequencies and percentages were used to analyse socio-economic characteristics of the respondents and constraints militating them from accessing agricultural information, while chi-square statistics were used test the independence using cross tabulation (bivariate table).

\section{RESULTS AND DISCUSSION}

Socio-economic characteristics: Socio-economic characteristics play a major role in determining the media through which farmers receive information Wakesho et al. (2018:112). In this study, the results show that the majority of the respondents were over the age of fifty and were males. Most of the respondents went up to high school level of education. More respondents had a land size of up to five hectares. The data depicted in Table 1 reflects the socioeconomic characteristics of the respondents which include age, gender, and marital status, and religion, educational level, farming experience and farm size. These characteristics exert their pressure on the attitude and behaviour of an individual (Rehman et al., 2013).

Table 1. Socio-economic characteristics of the respondents $(\mathrm{N}=120)$.

\begin{tabular}{|c|c|c|}
\hline Variables & Frequency & Percentages \\
\hline \multicolumn{3}{|c|}{ Age } \\
\hline Up to 35 & 28 & 23.3 \\
\hline $23-50$ & 38 & 31.7 \\
\hline$>50$ & 54 & 45.0 \\
\hline \multicolumn{3}{|c|}{ Gender } \\
\hline Male & 69 & 57.5 \\
\hline Female & 51 & 42.5 \\
\hline \multicolumn{3}{|c|}{ Marital status } \\
\hline Single & 45 & 37.5 \\
\hline Married & 63 & 52.5 \\
\hline Separated & 1 & .8 \\
\hline Divorced & 11 & 9.2 \\
\hline \multicolumn{3}{|c|}{ Religion } \\
\hline Christianity & 114 & 1.7 \\
\hline Islam & 4 & 3.3 \\
\hline Other & 2 & 95.0 \\
\hline \multicolumn{3}{|c|}{ Educational level } \\
\hline No formal education & 6 & 5.0 \\
\hline
\end{tabular}




\begin{tabular}{|c|c|c|}
\hline Primary & 21 & 17.5 \\
\hline Middle & 26 & 21.7 \\
\hline High & 46 & 38.3 \\
\hline College & 16 & 13.3 \\
\hline University & 5 & 4.2 \\
\hline \multicolumn{3}{|c|}{ Farming experience } \\
\hline $1-5$ years & 51 & 42.5 \\
\hline 6-10 years & 27 & 22.5 \\
\hline $11-15$ years & 9 & 7.5 \\
\hline $16-20$ years & 12 & 10.0 \\
\hline$>20$ years & 21 & 17.5 \\
\hline \multicolumn{3}{|c|}{ Farm size } \\
\hline Less than 5 hectors & 71 & 59.2 \\
\hline 5 hectors and above & 49 & 40.8 \\
\hline
\end{tabular}

Table 1 shows that $45 \%$ of respondents were over 50 years of age. A high percentage of aged farmers involved in farming was also found by Fasina (2013), this is not a good indication of improved productivity because as farmers get older their productivity decreases.

According to Table 1,57.5\% of the respondents were male while 42.5 were females. This implies that gender differences in productivity are systematic and persistent. Whether in agriculture or off the farm, among those selfemployed or in wage employment, women exhibit lower average productivity and earn lower wages than men. These differences have been documented in both developed and developing countries, and although they have declined over time (primarily as a result of the reduction in the education gap), they remain significant World Development Report (2012).

According to Table 1, 52.5\% of the respondents are married, $37.5 \%$ are single, $9.2 \%$ divorced while $0.8 \%$ separated. The fact that majority of the respondents are married may imply that couples are engaged in a cooperative effort in farming activities.

Table 1 shows the distribution of the farmers by their level of education. The majority (38\%) went up to high school level. Data related to the educational status of farmers revealed that these farmers are able to read and write.

As depicted in Table 1, the majority of the sampled farmers $43 \%$ had up to five years of farming experience. The study found that $59 \%$ of the farmers have land of about 5 hectares of land. This demonstrates that insufficient land availability is still a challenge that many farmers are facing. However, the High Level of Expert on Food Security and Nutrition (HLPE, 2013), asserts that a large share of food in Africa is produced by smallholders. The relationship between socio-economic characteristics of respondents and their access to agricultural information. Farmers' access to agricultural information is an important variable, which may be influenced positively or negatively by the socio-economic characteristics such as age, gender, educational level etc. Respondents' access to agricultural information was calculated using chi-square statistics to test the level of independence using cross tabulation (bivariate table) with various sources such as print media, television, extension staff, private sector and radio. The data to this regard is presented in Table 2 below.

Table 2. Magnitude of association between selected variables and source of information.

\begin{tabular}{lcccccc}
\hline \multirow{2}{*}{ Variables } & \multicolumn{5}{c}{ Source of information } \\
\cline { 2 - 7 } & Print media & Fellow farmers & Television & Extension personnel & Private sector & Radio \\
\hline Age & 0.006 & 0.128 & 0.033 & 2.06 & 0.665 & 3.356 \\
Gender & 0.100 & 0.689 & 0.411 & 0.686 & 0.110 & 0.268 \\
Educational level & 0.008 & 0.424 & 0.005 & 0.985 & 0.393 & 0.911 \\
Farming experience & 0.183 & 0.109 & 0.094 & 0.955 & 0.110 & 0.897 \\
Personal experience & 0.775 & 0.621 & 0.855 & 0.800 & 0.686 & 0.847 \\
\hline
\end{tabular}


Table 2 shows that there is a significant relationship between respondent's age and their sources of information. Age of respondents showed a significant relationship: print media with a $\mathrm{P}$ value 0.006 and Television with the P-value: .033. The data in Table 2 show gender of respondents had a non-significant relationship with their access to agricultural information. The non-significant relationship reveals that access to agricultural information was unlikely to be influenced by respondents' gender. The data in Table 2 indicate that there existed a highly significant relationship between education of the respondents and their access to agricultural information. The $\mathrm{P}$ value illustrates a positive relationship; which indicates that with the increase in the educational level of the respondents, there was an increase in their access to information. The results of the present study are in line with those of Katungi (2006) who found in his study in Uganda" that educated farmers had more access to information.

The data in Table 2 explain that there existed a nonsignificant relationship between the farming experience of the respondents and their access to agricultural information. The non-significant relationship reveals that farming experience of the respondent had no effect on their access to information.

Table 3. Rank order of access level on different information sources.

\begin{tabular}{lcccc}
\hline Information source & Rank & Yes & No \\
\hline Fellow farmers & 1 & $107(89.2)$ & $13(10.8)$ \\
Personal experience & 2 & $105(87.5)$ & $15(12.5)$ \\
Extension staff & 3 & $95(79.2)$ & $25(20.8)$ \\
Radio & 4 & $87(72.5)$ & $33(27.5)$ \\
Television & 5 & $57(47.5)$ & $63(52.5)$ \\
Print media & 6 & $43(35.8)$ & $77(64.2)$ \\
\hline
\end{tabular}

In Table 3, findings revealed that fellow farmers (89.2) and personal experience (87.5) were most preferred information sources among farmers. These findings are similar to those of Nosheen \& Ahmad (2010) where they reported "other farmers" and "personal experience" leading information sources among farmers. However, sources of information such as television and print media were the least sources of information sources used by farmers. This might be attributed to the fact that in the study area the majority of small scale farmers reside in rural areas and do not have access to sources of information such as television and also they do not easily access print media as in the peri-urban areas.

Constraints faced by farmers on information access in study area: Various constraints were discovered which militate against information access by farmers in the study area. The results are shown in Table 4 .

Table 4. Constraints hindering information access.

\begin{tabular}{lc}
\hline Constraint & Percentage \\
\hline Distance from the extension office & 72.5 \\
Lack of awareness of new technology & 72.5 \\
Lack of visibility of the extension agent & 70.8 \\
Lack of money & 67.5 \\
Lack of access to roads & 60.8 \\
\hline
\end{tabular}

Table 4 indicate that distance from extension office was leading constraint among $72.5 \%$ respondents. About $72.5 \%$ respondents perceived lack of awareness of new technology as a constraint. Lack of visibility of the extension agent was perceived as constraint among $70.8 \%$ respondents. Lack of money was perceived as a constraint among $67.5 \%$ while lack of access to roads was perceived a constraint by $60.8 \%$ respondents.

\section{CONCLUSION AND RECOMMENDATIONS}

It can be concluded that the majority of the respondents were over the age of fifty and were males. Most of the respondents went up to high school level of education. More respondents had a land size of up to five hectares. A significant relationship existed between respondents' age, education and their sources of information. The major sources of information used by farmers were fellow farmers and extension staff. The respondents identified constraints such as: distance from the extension staff and lack of awareness of new technology as the constraints that they faced in accessing agricultural information. This study recommends that, as small-scale farmers in the study area access information through fellow framers and personal experience, field extension staff should be distributed evenly in different areas for effective dissemination of 
agricultural information. Extension offices should be nearer to farmers for easy access to agricultural information farmers may need.

\section{ACKNOWLEDGEMENT}

This research was supported by Department of Agriculture Forestry and Fisheries

(DAFF) under the auspices of Food Security and Safety, North-West University. I thank Professor Babalola, the Director of Food Security and Safety who made it possible that this project is funded. I also thank KgaleNtle Projects under Thebe Tebogo Bokkie for assisting with data collection for this study. The results could not have been achieved without their assistance.

Finally, I would like to express my gratitude to the participants (farmers) for sharing their pearls of wisdom with us during the course of this research.

\section{REFERENCES}

Abbas, M., Lodhi, T. E., Bashir, A., \& Mahmood, M. A. (2008). Dissemination of wheat production technologies and interface of out-reach efforts with farmers. Journal of Agricultural Research (Pakistan).

Alvi M.H. (2016). A Manual for Selecting Sampling Techniques in Research. https://mpra.ub.unimuenchen.de/70218/1/MPRA_paper_70218.pdf.

Bawa, B.D. \& Bzugu, P.M. (2014). Influence of Sources of Information on Maize Farmers in Southern Borno, Nigeria. New Media and Mass communication Paper, 31(2), 2224-3267.

Ditau GEO-informatics Solution, (2016). District Rural Development Plan Ngaka Modiri Molema District Municipality North- West Province.

Davis, S. (2016). Sustainable Development - North West Province. Retrieved from: http://sharondavis.co.za/content/view/64/33/ on 29 November 2016.

Fasina. 0.0. (2013). Farmers' Perception of the effect of aging on their agricultural activities in Ondo State, Nigeria. The Belogradchik Journal for Local History, Cultural Heritage and Folk Studies, 4(3), 371-387.

Gerald F. O. \& King. R. P. (2006). Small-scale farmers in South Africa: Can agricultural cooperatives facilitate access to input and product markets? Department of Applied Economics: College of agricultural, food, and Environmental Sciences, University of Minnesota.

High Level Panel of Experts on Food Security and
Nutrition (HLPE, 2013), Vol.6 FAO, Rome.

Katungi, E. (2006). Social Capital and Technology Adoption: The Case of Banana Production Technology in Uganda. PhD Dissertation, University of Pretoria, Pretoria.

Khapayi., M. \& Celliers P.R. (2016). Factors preventing emerging farmers to progress to commercial agricultural farming in King Williams Town area of the Eastern Cape. South Africa. Journal of Agricultural Extension. 4(1), 56-68.

Mahikeng Local Municipality. (2017). IDP (2017-2018) http://www.mahikeng.gov.za/idp2017-18.

Mittal, S., \& Mehar, H. 2015. What Factors Influence Farmers' Choice of Information SOURCES? India, New Delhi. https://ccafs.cgiar.org/blog/whatfactors-influence-farmers $\% \mathrm{E} 2 \% 80 \% 99$-choiceinformation-sources\#.W874xvmxW1s.

Mburu, P. (2013). Factors influencing access to agricultural information by smallholder farmers through ICT channels in Deiya location Kiambu County (Doctoral dissertation, MSc Dissertation).

Nosheen, F., T. \& Ahmad, M. 2010. Analysis of genders specific sources of information regarding home and farm practices in Potohar region: a case study. The Journal of Animal and Plant Sciences, 20(1), 56-59.

Obidike, N. A. (2011). Rural Farmers' Problems Accessing Agricultural Information: A Case Study of Nsukka Local Government Area of Enugu State, Nigeria.

Ortmann, G.F. \& King, R.P. (2007). Agricultural cooperatives II: Can they facilitate access of smallscale farmers in South Africa to input and product markets? Agrekon, 46 (2), 219-244.

Rehman, F., Muhammad, I, Ashraf, I., (2013). Effect of farmers' socioeconomic characteristics on access to agricultural information: Empirical evidence from Pakistan. The journal of Animal and Plant sciences, 23(1), 324-329.

Ronald, B. Silayo, G. \& Abdalah K.J. (2015). Preference Sources of Information Used by Seaweeds Farmers in Unguja, Zanzibar. International Journal of Academic library and information Science, 3(4), 106-116.

Sanap, K. (2014). Role of Information and Communication Technology in the Women Empowerment. Retrieved from: http://www.nevillewadia.com/images/Cronicle2 
015/Dr.-Manohar-K.-Sanap15.pdf on 29 November 2016.

Shuttleworth, M. (2008): Descriptive research design. Retrieved from https://explorable.com/descriptive-researchdesign on 9 May, 2018.

Torres, R. J. (2017). The importance of qualitative research. https://www.quora.com/What-is-theimportance-of-quantitative-research-1

Wakesho, G., Pittchar, J., Midega, C., Zeyaur, K. (2018). An assessment of effectiveness of participatory video and drama in enhancing learning of "Climate Smart" push-pull technology: A case study of
Butere and Vihiga farmers in Western Kenya. International Journal of Agricultural Extension, 06 (02), 109-115.

World Development Report (2012). Retrieved from http://siteresources.worldbank.org/INTWDR201 2/Resources/7778105$1299699968583 / 7786210-$

1315936222006/chapter-5.pdf on 19/12/2016.

Young, J. (2016). Investing in North West: South Africa Info. South Africa. Retrieved from: http://www.southafrica.info/business/investing/ opportunities/northwest.htm\#.WC1x6MkqwxM, on 17 November 2016. 